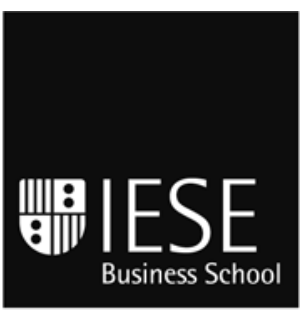

University of Navarra
Working Paper

"la Caixa" Chair of Corporate Social

WP no 693

Responsibility and Corporate Governance
May, 2007

\title{
ETHICAL MANAGEMENT SYSTEMS FOR NOT-FOR-PROFIT ORGANIZATIONS
}

\author{
Antonio Argandoña
}

\section{IESE Business School - University of Navarra}




\title{
ETHICAL MANAGEMENT SYSTEMS FOR NOT-FOR-PROFIT ORGANIZATIONS
}

\author{
Antonio Argandoña*
}

\begin{abstract}
Non-governmental organizations (NGOs) have proven to be excellent instruments for promoting a wide range of causes. But they need to adhere to strict ethical principles that they usually defined in voluntary codes and standards. This paper analyzes the "Ethics. NGO management system" standard, published by Aenor, a private Spanish organization committed to the development of standardization and certification. The analysis and comments are centered mainly on NGO accountability issues.
\end{abstract}

* Professor of Economics, IESE

Keywords: Not-for-profit organizations, non-governmental organizations, NGO, code of ethics, standard. 


\section{ETHICAL MANAGEMENT SYSTEMS FOR NOT-FOR-PROFIT ORGANIZATIONS}

\section{Introduction ${ }^{1}$}

Non-governmental or "third sector" organizations (NGOs) have grown rapidly in number, size and influence in recent decades. This third sector is made up of "not-for-profit organizations governed by private law and with independent legal status, pursuing programs of general interest for the improvement of society in the fields of social welfare and sustainability: community action, education, healthcare, environmental protection, development cooperation and sustainable development" (A enor, 2004, \#1).

NGOs have proven to be excellent, alongside governments and corporate social initiatives, for promoting a wide range of causes. In any case, they contribute effectively to achieving important social objectives; they have proved to be selfless and effective; and their organizational flexibility has enabled them to address new opportunities. As a result, they are generally held in high public esteem in both developed and developing countries.

More recently, however, NGOs have faced a number of serious challenges. The influence of globalization, technological progress, rising standards of living in advanced countries and also in many emerging countries, etc., on the one hand, have changed the political, social, economic and human framework in which NGOs operate. People have become more sensitive to the problems (hunger, disease, income inequalities, lack of opportunity, impact of natural and manmade disasters, etc.). They also realize that many of these problems could be overcome, or at least alleviated, by companies (given greater financial resources, information technology, communications, technological progress, etc.). And their values have changed (solidarity, awareness, volunteering, compassion, etc.). All this has given a new dimension to aiding the disadvantaged, which is the basis for both the demand and the supply of NGO services.

In response, the role, number, scale and function of NGOs have changed. Sometimes NGOs take over the role of governments; other times they are subordinate or complementary to governments. In some cases they have replaced or become a channel for individual

\footnotetext{
${ }^{1}$ This study is part of the work of the "la Caixa" Chair of Corporate Social Responsibility and Corporate Governance at IESE. I would like to thank Daniel Galland for his help in gathering documentation for this study.
} 
philanthropy or charity; in others they obtain funds from government, or even from companies, which have themselves become agents of change by becoming involved in the community. The size and scope of NGOs has grown. Nowadays, some are multinationals, substituting or partnering with international bodies and playing a role as economic and political actors on the international stage, where they often set the agenda. The number and variety of areas in which NGOs are involved has expanded to include immigration, dependant care, human rights advocacy, peace promotion, the fight against specific diseases, or pressure for acts of corporate social responsibility (Eisenberg, 2000).

All this has prompted a thorough reconsideration of the principles that govern NGOs, the way they are organized, and how they operate. Precisely because they move significant amounts of resources for what sometimes are crucially important human and social projects, they are expected to be, not only financially sustainable, but also effective and efficient. ${ }^{2}$ As social and political actors, they must adhere to the rules of ethics and honesty, and show commitment to protecting the environment. While demanding transparency and disclosure from companies, they must follow the same principles. They must cultivate their image and reputation, because it affects their legitimacy and, therefore, their survival, individually and as a sector. And they must strive to be agents of change not only with respect to social outcomes, but also with respect to society's attitudes and values. ${ }^{3}$

In view of the above, it is understandable that NGOs should have been criticized, across the board and in specific cases, for neglect of their original goals, lack of legitimacy, inefficiency, lack of transparency, etc. (Zaidi, 1999; Foote, 2001; Gibelman and Gelman, 2001, 2004; MacDonald et al., 2002). ${ }^{4}$

For all these reasons, numerous attempts have been made to self-regulate NGOs through codes of conduct, codes of ethics, rules of behavior, recommendations, good practices, etc. These documents serve a variety of purposes: they define what is accepted or acceptable behavior, promote high standards of practice, provide benchmarks for self-assessment, establish frameworks for members' conduct and responsibilities, help avoid problems of collective action (when various organizations are affected), etc.

The next section of this paper explains the role of ethical codes as instruments to control and regulate NGOS. The following section discusses the contents of a Spanish standard published in 2004. The article concludes with some comments on this standard from the point of view of accountability. ${ }^{5}$

\footnotetext{
${ }^{2}$ NGOs pose a challenge to the very concept of economic efficiency, because in those organizations there is not a clear distinction between inputs and outputs. "Should a volunteer's time be treated as an input if the volunteer herself is enriched by the experience?", asks Wells (2006), pp. 7-8).

${ }^{3}$ Other reasons are insufficient government oversight, absence of direct voter or stakeholder regulation, increasing media coverage and public scrutiny from scandals in the NGOs sector, shift from government funding toward direct funding of nonprofits, the belief among donors that NGOs are more effective than governments in providing basic social services, that they are better able to reach the poor, and that they are key players in democratizations processes, and the belief of the NGOs members that accountability "is the right thing to do" (Bies, 2001; cfr. also Edwards and Hulme, 1996; Light, 2000).

${ }^{4}$ Fowler (1997) pillories NGO "pretenders", such as the BRINGOs (Briefcase NGOs), CONGOs (Commercial NGOs), FANGOs (Fake NGOs), CRINGOs (Criminal NGOs), GONGOs (Government-owned NGOs), MANGOs (Mafia NGOs), PANGOs (Party NGOs), etc.

${ }^{5}$ Unerman and O'Dwyer (2006) allude to the absence of studies on the accountability mechanisms within the third sector.
} 
Accountability is an important issue because of the influence that NGOs have on the life of many people, including those that are not the direct object of the NGOs' promoted policies. ${ }^{6}$ Organizations may be considered responsible solely to themselves or to their owners. Alternatively, they can also be accountable to those stakeholders who have the most power to influence the organization's actions, or to society as a whole, especially clients or beneficiaries of the NGOs' operations. Then, there is a variety of alternative accountability meanings, from identity accountability (the NGO is answerable to itself and to its members through its values, mission and culture), to accountability to the owners (for example, the core activists that control the NGO), to those stakeholders who have the ability to influence the results of the organization, or to all those stakeholders upon whom the NGO's actions have or may have an impact (Unerman and O'Dwyer, 2006).

\section{Codes of Ethics for NGOs}

Lloyd (2005) identifies six reasons for self-regulation in the NGO sector: 1) The rapidly increasing number of NGOs and their growing influence has made them key players in society, which demands responsibility and accountability. 2) NGOs' success in changing national and international policy has led other agents (governments, companies, unions and public opinion) to question their legitimacy. 3) Their rapid growth has outpaced the ability of many governments to effectively regulate the areas in which NGOs operate. 4) Even in countries with proper regulation, self-regulation is seen as a way of going beyond the legal minimum to promote higher standards of governance and accountability. 5) NGOs need to maintain society's trust, and to do that they must meet higher standards in their own organization and operations. 6) The need to diversify sources of funding and attract other donors makes self-regulation a necessity.

Self-regulation can be achieved in many different ways along a continuum between two extremes: codes of conduct, on the one hand, and accreditation and certification systems on the other. Codes of conduct are self-regulatory mechanisms where groups of organizations agree on standards governing their conduct, with each promising to abide by established norms. Accreditation and certification systems are self-regulatory systems involving independent external reviews of an organization's compliance with pre-established standards and norms (Shea, 2004). ${ }^{7}$

Codes are voluntary and lack enforcement mechanisms. This makes it more likely that NGOs will adopt them, and encourages their members to learn and adapt to the code's requirements. Codes can also be enforced indirectly through awareness of the impact of non-compliance on NGO reputation, or by making compliance a condition for access to certain sources of finance. ${ }^{8}$ Certification mechanisms are subject to external control and so are stricter (Leader, 1999), although they do not always have means of enforcement. In any case, enforcement mechanisms

\footnotetext{
6 "Accountability is generally defined as the means by which individuals and organizations are answerable to others and are held responsible by their actions" (Bies, 2001, p. 52). Cornwall et al. (2000, p. 3) suggest that there is an external dimension (about being held responsible by others) and an internal dimension (about taking responsibility for oneself). Cfr. Ebrahim (2003).

${ }^{7}$ Bies (2001, pp. 52-53) calls these types of systems "discretionary" and "mandatory self-regulation models."

${ }^{8}$ For example, the UK Disasters Emergency Committee requires that members be signatories to the Code of Conduct of the Red Cross and Red Crescent. And the Australian Council for International Development (CFID) limits access to Australian government funds to signatories of its Code of Conduct.
} 
vary greatly: publication of annual reports, external audits, committee oversight, complaint mechanisms, etc., depending on the needs of the sector in each country at any given time. ${ }^{9}$

It is generally recognized that the first code in the field of humanitarian aid was the Code of Conduct for the International Red Cross and Red Crescent Movement and NGOs in Disaster Relief (www.icrc.org). It stemmed from the recognition by some international NGOs of the poor quality of their work in Sudan in the late 1980 s. $^{10}$ The first self-regulation initiative, The Caucus of Development NGOs (CODE-NGO) Code of Conduct, was ratified in the Philippines in 1991 (Sidel, 2003), although there are important precedents. ${ }^{11}$ In the U.S., InterAction, a membership association of private voluntary organizations (PVOs) in 1993 developed a set of standards (InterAction, 2006). And a number of European and U.S. NGOs published in 2000 a Humanitarian Charter and Minimum Standards in Disaster Response (the "Sphere Standards"). Since then, the number of codes and similar documents has multiplied. ${ }^{12}$

Some codes, such as the Red Cross and Red Crescent code, or the World Association of Nongovernmental Organizations (Wango) Code of Ethics and Conduct for NGOs, are global in scope. Others are for individual countries (Sierra Leone, Philippines, Somalia, Botswana, Ethiopia, Zimbabwe, etc.). Still others apply to a particular NGO or group of NGOs acting collectively.

Some codes are basically statements of principle, like the Red Cross and Red Crescent code, BOND's Statement of Principles ${ }^{13}$ or the Caux Principles for NGOs, while others contain detailed rules of conduct, such as the Wango code mentioned earlier or, in Spain, the Code of Conduct of Development NGOs (www.congde.org). Some codes are aimed exclusively at NGOs, while others apply to other stakeholders as well (e.g., those regulating the conduct of NGOs in war zones, which are also intended to influence the behavior of the belligerents).

In content, some codes (e.g., Wango) are intended to offer guidance in all areas of NGO operations, while others emphasize certain specific aspects, such as accountability for donations, ${ }^{14}$ the battle against HIV/AIDs, ${ }^{15}$ or personnel management in aid NGOs. ${ }^{16}$ Some codes address all NGOs, others only particular subgroups, such as development NGOs or philanthropic organizations. ${ }^{17}$

In what follows, we shall be considering a particularly interesting instrument: the experimental Spanish standard Ética. Sistema de gestión de las ONG (Ethics. An NGO management system), approved by Aenor in 2005. A enor (Spanish Association for Standardization and Certification) is a private, independent, not-for-profit organization committed to the development of standardization and certification in all industrial and service sectors. It is recognized nationally,

\footnotetext{
${ }^{9}$ See Lloyd (2005) for a list of NGO self-regulation systems and a list of self-regulation initiatives.

10 Sometimes, the International Red Cross and Red Crescent Movement - The International Committee of the Red Cross, the International Federation of Red Cross and Red Crescent Societies and its member National Societies are included in a separate category as Non-Governmental Humanitarian Agencies (NGHAs).

11 "In the US non profit context, the history of mandatory self-regulation models begins in 1918 with the creation of the National Charities Information Bureau (NCIB)" (Bies, 2001, p. 56).

${ }^{12}$ Naidoo (2004) estimates that self-regulation initiatives exist in 40 countries worldwide.

${ }^{13}$ BOND is a network of over 290 UK-based voluntary organizations (www.bond.org.uk).

${ }^{14}$ Cf. BBB Wise Giving Alliance Standards for Charity Accountability (www.give.org).

${ }^{15}$ An example is the Code of Good Practice for NGOs Responding to HIV/AIDS, promoted by eleven NGOs (www.ifrc.org).

${ }^{16}$ People in Aid Code of Good Practice in the Management and Support of Aid Personnel (2003), updated version of People in Aid Code of Best Practice (1997) (www.dochas.ie).

17 For example, the Statement of Values and Code of Ethics for Charitable and Philanthropic Organizations (www.independentsector.org), or the ePhilanthropy Code of Ethical Online Philanthropic Practices (www.ePhilanthropy.org).
} 
at a European level, and internationally. It develops standards and certificates in quality management, environmental management, risk prevention auditing, etc.

\section{The Spanish Standard for Ethical NGO Management}

In 2000, Aenor decided to prepare, with the help of a working group of experts and NGOs representatives, a set of standards for the design of ethical, social and environmental management systems in companies and other organizations. Out of this work came the standard named Ethics. NGO management system, approved in 2004. This is the first standard produced in Spain to "define the requirements of an ethical management system in NGOs" (Aenor, 2004, \#1).

Unlike the codes, principles and good practices mentioned previously, the Aenor standard is not intended as a tool of industry self-regulation, although people who work in NGOs helped to prepare it (alongside academics, unions, consultants, etc., but not employers' representatives). The standard is sponsored by Aenor, which is not attached to any NGOs; its purpose is to inform, guide NGO management, certify, and demonstrate conformity or nonconformity. It is therefore a mechanism of external control, not by the political authorities but by civil society, or part of it, which is what makes it particularly interesting.

It is a voluntary standard, so any NGO that wishes to may submit to the certification process and obtain the certificate that proves compliance with the standard. This has obvious advantages for an NGO's reputation, and also for its management (in that it will be aware of its own situation and the ethical quality of its actions). It is not merely a declaration of principle, but nor does it go into full regulatory detail. Every organization that seeks certification must develop its own conception of ethical management, draw up its own documents (code of conduct, etc.), acquire commitments, establish mechanisms for continuous assessment of its ethical management, and devise its own indicators. Thus, the standard leaves it to each individual NGO to set its own goals and methods, but demands a certain minimum ethical content.

The standard applies to Spain (in fact, the problems of NGOs working in developing countries are not considered). And it is experimental and subject to periodic revision, as is to be expected in a new and changing field, where experience in applying the standard is an important input to the improvement process. Annex 1 shows the index of the Aenor standard.

In what follows we shall briefly discuss the most noteworthy aspects of the Ethics. NGO management system standard, comparing it with other codes and with the literature on ethical problems in NGO management. We will not be dealing with the more technical and organizational aspects discussed in the sections of the standard designed to offer guidance to NGOs on the development and implementation of an ethical management system. ${ }^{18}$ Our interest is in the discussion of the accountability issues of NGOs.

\footnotetext{
${ }^{18}$ The standard suggests, for example, that compliant NGOs must establish, document, implement and maintain an ethical management system (\#4.1.a and 5.1), draw up an ethics code (\#4.1.b), create an ethical management committee (\#5.3), develop indicators for their ethical management system (\#5.4), identify stakeholders and their representatives (\#4.1.c), provide them with the necessary information (\#4.1.g), regularly renew their governing bodies (\#4.1.j), run audits of the ethical management system (\#5.5), and create a continuous improvement system (\#5.6). Lastly, almost all the sections include a requirement to document actions and incidents. Many of these points are found in other codes, where they tend to be treated in more detail (e.g. Wango, 2004). On ethical, social and environmental management systems, see Argandoña (2004).
} 
The standard does not give an explicit definition of NGOs. Instead, it describes them as "notfor-profit organizations governed by private law and with independent legal status, pursuing programs of general interest for the improvement of society in the fields of social welfare and sustainability: community action, education, healthcare, environmental protection, development cooperation and sustainable development" (\#1). ${ }^{19}$

There are some ambiguities in this definition. For example, no distinction is made between non-governmental organizations (NGOs), private voluntary organizations (PVO), and not-forprofit organizations (NPO). ${ }^{20}$ The distinction between these types of organizations may be legal, economic, financial (source of funding), functional (functions performed) or structuraloperational (Vakil, 1997). ${ }^{21}$

However, any attempt at clarification runs into difficulties. For example, if we emphasize the voluntary nature of NGOs' work, we ignore the trend toward professionalization, driven by the need to accomplish their mission satisfactorily. ${ }^{22}$ An important part of the definition is the private, non-governmental nature of NGOs (although the increasing tendency for governments to use NGOs to channel state aid puts a question mark over this distinction), ${ }^{23}$ their non-profit-seeking nature, their stability ${ }^{24}$ and management autonomy, the fact that they are formally constituted (which excludes some informal NGOs, typical of developing countries), and their non-violent methods (Martens, 2002). ${ }^{25}$ The idea of NGOs as an active and representative part of civil society is attractive, but highly debatable (Abramson, 1999). ${ }^{26}$

In any case, it seems only natural that the Spanish standard should not address these (and other) debates over terminology or the definition of what an NGO is or is not, ${ }^{27}$ as its purpose is to offer guidance on the ethical management systems of institutions which, in any case, act on various criteria from companies (which are subject to different standards), just as most codes do not go into precise definitions. And yet, the list of activities "of general interest for the improvement of society in the fields of social welfare and sustainability" used to define the purpose of the standard seems very incomplete. It could be expanded to include, for instance, welfare, development, advocacy, education, networking and research, to offer a broader perspective. The standard makes no reference to the level at which NGOs operate (international,

\footnotetext{
${ }^{19}$ Quotations from the standard are given with the paragraph number.

20 "Not-for-profit" seems preferable to "non-profit", in the sense that an NGO does not aim to make a profit, but may do so on occasion - although profit is never distributed among the owners or members.

${ }^{21}$ Ruiz (2000), in an overview of the nonprofit sector in Spain, includes associations, foundations, cooperatives, mutual provident societies, schools, sports clubs, savings banks with social welfare activities, and hospitals. Obviously, not all these can be described as NGOs.

${ }^{22}$ NGOs are voluntary in another sense, too: they are set up by private initiative and voluntary commitment, rather than in response to a legal requirement (Wango, 2004, II.E.1).

${ }^{23}$ This is apparent in the case of GONGOs (government-organized organizations), created by developing country governments to capture aid funds from developed countries; and, in the advanced countries, QUANGOs (quasinongovernmental organizations), financed almost exclusively from public funds. Also, DONGOs (donor-organized organizations), created by donors to channel their donations, lack independent management (Vakil, 1997).

${ }^{24}$ Cf. Coordinadora de ONG para el desarrollo (1998).

${ }^{25}$ Their strong grass-roots support and hence their ability to identify the problems of their constituents and then tailor assistance to meet their needs (Nalinakumari and MacLean, 2005) is not a defining trait, but a consequence of their success.

${ }^{26}$ For a point of view favorable to the identification of NGOs with civil society, See Edwards (2000). The Caux Principles for NGOs make service the fundamental principle, defining service in terms of the function that each NGO voluntarily assumes in civil society. This fundamental principle is the basis for the other, "derivative" principles: independence, representation, participation, respect for the law, care, integrity and accountability.

27 The standard defines the third sector as a "set of legally constituted, aid-oriented not-for-profit organizations governed by private law and with independent legal status" (\#2).
} 
regional, national or community-based), although the nature of the problems are likely to be very different in each case.

\section{The Principles}

The standard's point of departure is the fact that every NGO has certain values, ethical and social principles that define its mission and activities. As in ethics codes, the list of principles given in the standard is merely indicative and declarative: the intention is not that these and only these principles are relevant, but that NGOs must have "their own values and principles," which ideally should be "aligned or complementary to those listed here" (\#3.1). In any case, it appears that the principles are intended to serve as an ethical guide for the organization, its policies and its actions, and as rules for interpreting subsequent recommendations.

The standard briefly outlines the principles in three blocks, basically corresponding to the three main NGO stakeholder groups (though the term "stakeholder" is not used). Definitions of the principles are not provided.

The principles relating to the individual are: (recognition of) human dignity, defense of the rights of the individual (which it is assumed are synonymous with human rights), ${ }^{28}$ and solidarity. The principles relating to society are: trust (NGOs must generate trust), openness (they must have a positive influence on the social environment and be receptive to society's demands), and cooperation (with other agents). The internal principles, aimed at the organization itself, are: legality, transparency, management effectiveness and efficiency, professionalism, continuous improvement, participation, and decentralization and demarcation of decision making.

Merely listing these principles does not seem particularly illuminating. Compared to the lists of principles given in other codes, little effort appears to have been made to specify all the principles that are really important for this standard. Or at least, the distinction between these principles and the requirements discussed later is unclear, as the requirements (transparency and accountability, for example) obviously must be based on the principles. The principles of professionalism and continuous improvement overlap, as professionalism is defined in terms of "constantly improving the ethical and technical knowledge, know-how and judgment of paid and voluntary staff" (\#3.4), while continuous improvement is defined as "setting goals and identifying opportunities to improve the organization" (\#3.4). All the same, we must not forget that the standard is aimed at the implementation of a management system in NGOs, which entails an emphasis on continuous improvement both in individuals and in the organization.

The principle of cooperation ("to include networking with other social and political organizations among their purposes and plans," \#3.3) does not necessarily apply to all NGOs, ${ }^{29}$ just as the separation of decision-making among governing and management bodies probably makes little sense in small NGOs. However, if the standard is part of an effort to improve NGOs' technical and economic organization, this principle seems valid, though it is unlikely to be as important as others.

\footnotetext{
${ }^{28}$ This principle would have been clearer if it had been linked to the Universal Declaration of Human Rights and if some of the fundamental rights had been made explicit, as in Wango (2004), I.C and D.

${ }^{29} \mathrm{~A}$ similar principle appears in other codes; for example, Wango (2004), I.A.
} 


\section{Recommendations Given in the Standard}

The standard uses the stakeholder scheme to organize its recommendations, as shown in Table 1. It does not include a section on internal aspects of NGO management (integrity, structure and responsibilities of governing bodies, political independence, financial management, etc.).

\section{Owner-Shareholders: Members, Cooperative Members, Sponsors, Executive Committee}

In this section, the standard (\#4.2) borrows the terminology and analysis of corporate social responsibility and business ethics, as exemplified by the use of the term "owner-shareholders", which is inappropriate. In any case, the generic term "members" refers to "individuals or corporations that exercise sovereignty over the organization" (\#2). In a company this would be the owners, the shareholders, or their representatives; in an NGO, it would include the members (in associations), cooperative members (in cooperatives), patrons or sponsors (in foundations), and members of the executive committees. The duties of an NGO, which are rights of the members, are described as follows: ${ }^{30}$

1) Duties inherent in membership: equal rights and duties, fair treatment, right to be heard and to voice complaints, ${ }^{31}$ non-discrimination, participation, equal opportunity, transparency in electoral processes, etc.

2) Disclosure duties: about members' rights and duties, the organization's mission and values, its actions and financial performance, etc. In the case of sponsors and managers, the standard emphasizes the right to information for decision making, and the need for "channels and indicators to directly ascertain the degree of satisfaction and fulfillment of the rights of all interested parties" (\#4.2.2.c).

3) Training duties, in the case of sponsors and managers.

Contributors of Funds

Many of the ethical problems in NGO management have to do with fundraising, which is even more important for NGOs than it is for companies. This is due to the fact that raising and channeling funds is often their primary mission, and also because the continuing trust of the contributors of funds is crucial to NGO survival. ${ }^{32}$

First, the standard establishes, that "the organization must seek funds in accordance with its mission" (\#4.3.1), which implies that establishing the NGO's mission and goals is a precondition

\footnotetext{
${ }^{30}$ For an analysis of some of the ethical problems presented here, see Lehr-Lehnardt (2005) and Gibelman and Gelman (2004).

${ }^{31}$ This right seems to refer to members' status as customers, as in the case of members of a cooperative, rather than as members per se (\#4.2.1.c).

32 On the ethical problems of fundraising in NGOs, see Zaidi (1999), Fisher (1997), Vernis (2001), Lehr-Lehnardt (2005), Brown and Kalegaonkar (2002), Gibelman and Gelman (2004).
} 
for fund raising..$^{33}$ And secondly, that it "must manage them effectively and efficiently for the purpose for which they were given" (\#4.3.1). ${ }^{34}$

Among contributors of funds, the standard (\#2) includes donors ("individuals or companies that make contributions in cash or in kind to the organization for the pursuit of its activity for nil consideration"), sponsors ("those who contribute financial or material resources to an organization or one of its projects in order that the organization's values or attributes be associated with the sponsor's image"), and subsidizers (governments, insofar as they contribute funds to NGOs).

1) To attract donations, an NGO must demonstrate its achievements (Zaidi, 1999), which may tempt its managers to exaggerate the success of their previous initiatives and the benefits obtained. NGOs have a fiduciary obligation towards their donors that may sometimes be legally enforceable. That is why an NGO's first duty to its contributors of funds is disclosure and accountability. ${ }^{35}$ The standard includes a general duty to disclose information on the organization's mission, values, governing bodies, programs, etc., not as part of the general duty of disclosure to society, but specifically to the contributors of funds, so as to inform their decision making (including information about negative aspects of the NGO's management: complaints, claims, inspections, legal disputes and audit results). It also states a duty to inform about the use of funds, not only at the end of the project, but also during the project, and to report on compliance with this standard (\#4.3.5).

2) With respect to donors (\#4.3.2), the duty of disclosure and accountability includes disclosure of the ratio of fundraising costs and overhead costs, on the one hand, to revenues, on the other; ${ }^{36}$ breach of commitments regarding the use of funds for projects (this is related to the principles of effectiveness and efficiency); and the duty to document the follow-up reports on the use of funds (which is natural if the aim is to develop a management system). Further on (\#4.3.5.a), the standard includes what we consider the very important principle of donors' limited liability, stating that donors must not be held "directly liable for specific problems and their solutions."

3) The standard pays particular attention to relations with sponsors, as they tend towards actions that distort an NGO's values and goals. It demands that sponsors respect "the NGO's independence of action" (\#4.3.3.e), in reference to the so-called sponsor-client problem (Zaidi, 1999). Hence the duty to make "full and transparent disclosure" (\#4.3.3.a) of the sponsorship process, probably because of possible conflicts of interest or deviation from the organization's

\footnotetext{
33 This is an fundamental ethical rule that is not always respected. The Economist (2000, p. 25) reported the following exchange: "A young man thrusts his crudely printed calling card at the visitor. After his name are printed three letters: NGO. 'W hat do you do?' the visitor asks. 'I have formed an NGO.' 'Yes, but what does it do?' 'Whatever they want. I am waiting for some funds and then I will make a project.'"

${ }^{34}$ NGOs must behave efficiently in two senses: decisions inside the organization must be taken in a rational way, and NGOs must show efficiency to the providers of funds. But both types of efficiencies do not provide the touchstone for NGOs' accountability (Wells, 2006).

${ }^{35}$ Unlike the owners of a company, who are entitled to the residual profit and control of the business, the contributors of funds have no right to supervise the NGO's management. What is established here is a right to monitor the use of the resources donated (Glaeser, 2002).

${ }^{36}$ The purpose of this is, among other things, to avoid careless management or management for the benefit of the NGO's staff, rather than its clients; excessive spending on marketing to attract donations; or generally putting fundraising before the NGO's goals.
} 
goals; ${ }^{37}$ the duty to establish "criteria and requirements for acceptance or rejection of potential sponsors, so as to foster consistency between sponsors' activities and the NGO's mission and values" (\#4.3.3.b); and the need for a collaboration agreement that prohibits behaviors that may compromise the NGO's mission and values (\#4.3.3.c). The standard also recommends that sponsorship relationships be long term (\#4.3.3.d).

4) With regard to subsidizers (governments), the standard first establishes a duty of consistency, so that the mere availability of government funds does not justify the acceptance of projects that are incompatible in content, scale or resource requirements with the NGO's mission and management capabilities (\#4.3.4.b), as this would compromise its effectiveness and efficiency, and even its legitimacy (Vernis 2001; Fisher 1997). ${ }^{38}$ Secondly, it establishes a duty of disclosure (\#4.3.4.c), which it defines more precisely and in more detail than the duty of disclosure to donors and sponsors.

The standard sees the relationship between contributors of funds and NGOs as one of supply and demand. The initiative may come from NGOs, which appeal for donations, or from contributors, who offer funds for specific projects. The standard then establishes the conditions for an ethically and technically correct and satisfactory relationship, supported by NGO accountability to donors. It does not consider the possibility of donors taking a more active role, catalyzing, encouraging and supporting the NGOs' work, assisting NGO self-regulation and making the public regulatory framework more effective, promoting government collaboration with NGOs, etc., as other initiatives have suggested. ${ }^{39}$

\section{Volunteers and Paid Staff}

Due to the very nature of NGO operations, human resources management in NGOs is very important. The standard deals with this issue at some length, although many of its

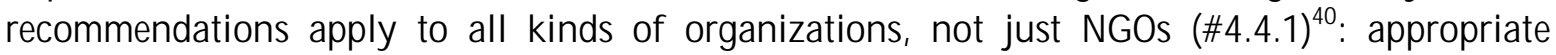
working conditions, a healthy and safe work environment, employees' right to express their own ideas and opinions (always within the framework of the organization's principles and values) (\#4.4.1.c), proper treatment of employees, staff motivation without exploitation (which is particularly important in this type of organization), information (especially about the projects being carried out), and participation.

In the case of paid staff (\#4.4.2), further recommendations include protection of employees' right to privacy, non-discrimination, hiring of people with disabilities, care to ensure that employees behave ethically in their daily tasks, an appropriate pay policy, transparent, free and competitive hiring, employee training, appropriate promotion criteria, disciplinary action and dismissal, and employee autonomy. Clearly, all these duties are not specific to NGOs, nor, within NGOs, do they apply only to paid staff, but also to voluntary workers. ${ }^{41}$ Only one section

\footnotetext{
${ }^{37}$ The standard does not deal specifically with NGO conflicts of interest, although they can be serious: an example is the conflict that arises when a member of management has a personal interest in the decision on which project to finance. Cf. MacDonald et al. (2002). Other codes address this issue explicitly in various dimensions; for example, Wango (2004) deals with conflicts of interest within NGO governing bodies (IV.E) and among NGO staff (V.B).

${ }^{38}$ On the problem of NGO legitimacy, see Edwards and Hulme (1996).

${ }^{39}$ For example, USAID (1995), InterAction (2006).

${ }^{40}$ On this type of problems in NGOs, see Foote (2001).

${ }^{41}$ The duty to guarantee privacy and confidentiality of information, however, applies to all the people or institutions with which an NGO has dealings (\#4.1.f).
} 
is specific to paid staff and NGOs: "trial periods may not take the form of voluntary work" (\#4.4.2.j).

Voluntary workers play a particularly important role in many NGOs, to which the standard pays special attention (\#4.4.3). It starts by saying that "the participation of volunteers in an NGO's activity must be based on criteria of social participation" (\#4.4.3.a). Some of the duties mentioned are an attempt to specify rules for volunteers that will generally apply to all staff, but are particularly important for volunteers, on account of their motivation and the fact that they cost NGOs almost nothing, which could lead some NGOs to take their efforts and achievements for granted. They include: an orientation process for new volunteers; volunteer job descriptions; volunteer recruitment based on criteria of effectiveness and efficiency; provision of sufficient training (to avoid amateurism) and material means; private health, accident and liability insurance in accordance with the risks of the job; reimbursement of expenses incurred in volunteering; clear differentiation between paid jobs and volunteer jobs; limited duration of volunteer commitments, etc.

Clients

The standard defines NGO's clients as the "recipients of the organization's goals and activities" (\#2). Obviously, the ethical problems that may arise in relations with clients are very important, as they directly affect the core of an NGO's mission and activities, and because the clients often are in a state of need. ${ }^{42}$ The standard takes it for granted that the NGO's mission and goals must be clearly defined, and specifies the organization's duties toward its clients as follows (\#4.5):

1) Disclosure about the ethical values and principles on which the ONG operates, the nature of the services it offers, and the client's contributions, rights and duties. Although many of the NGOs in Spain operate in other countries, the standard makes no reference to a problem common to NGOs working in other cultures: the sometimes unwitting propagation of Western values, especially in NGOs engaged in humanitarian aid, promoting the rights of women, children or minorities, as defined by Western society (The Economist, 2000).

2) Respect for clients, avoiding "arrogant, paternalistic or hierarchical attitudes" (\#4.5.b), promoting client participation, safeguarding the confidentiality of client data and privacy, etc. Paternalism is a frequent problem in NGOs, especially when working with marginal groups without resources or expertise, or when the NGO staff are deeply convinced of their ideas or have great respect and admiration for their founder (Brown and Kalegaonkar, 2002). Elitism can be a problem (Lehr-Lehnardt, 2005) when the staff are highly professional and become detached from the everyday lives and concerns of their clients. It is therefore crucial to establish channels of communication between NGO staff and the disadvantaged society in which they work. The standard does not include any prohibition of discrimination on the grounds of race, creed, nationality, political beliefs, etc.

3) Transparency: NGOs must avoid misleading promotions and not misuse client data to enhance their own representative status.

\footnotetext{
${ }^{42}$ On this type of problem, see Lehr-Lehnardt (2005), Brown and Kalegaonkar (2002), The Economist (2000).
} 
4) Accountability: the standard recommends that NGOs create mechanisms for assessing their own performance, establish procedures for processing complaints, suggestions and claims, and periodically measure client satisfaction, etc.

5) Effectiveness and efficiency: the duty to provide the promised level of services, or at least the level that is customary and legitimate.

6) Rejection of "payments, gifts or other practices that may constrain the freedom or influence the behavior of either party" (\#4.5.h). This requirement is aimed against a form of corruption (in client-NGO relations), although the term "corruption" is not explicitly used.

\section{Suppliers and Subcontractors}

The rules on relations with suppliers and subcontractors (and other providers, though not explicitly mentioned) are no different from those included in codes or standards for companies. The guiding principle is to "maintain the maximum level of internal consistency between the mission and overall objectives [of the NGO] and those of its subcontractors and suppliers" (\#4.6), just as a socially responsible company must endeavor to ensure that the goals and objectives of the participants in its value chain are compatible with its own.

The standard (\#4.6) formulates requirements for the selection and engagement of suppliers and subcontractors; the duty to inform suppliers and subcontractors about the ethical management system, policies, principles and anything that may be relevant to the contractual relationship; and the duty to take corrective measures if the conduct of suppliers or subcontractors does not comply with the desired ethical standards.

It also imposes an obligation to "take appropriate measures to guarantee that there are no payments, favors, gifts or other practices that might restrict either party's freedom to act in accordance with its legitimate interests or that might undermine the organization's principles" (\#4.6.e). The standard does not explicitly use the terms that define this type of problem (corruption, extortion, bribery, conflict of interests, etc.), but obviously this is what it is referring to in this section (as in \#4.5.h on relations with customers). ${ }^{43}$

\section{Competing Organizations}

Under the heading of competing organizations (\#4.7), the standard includes relations of competition/rivalry or collaboration with other NGOs, public sector entities (but not government bodies, which are dealt with in a later section), and private sector organizations. Inter-governmental organizations (IGO) such as United Nations agencies or European Union bodies are not included.

The general rule in relations between NGOs is that competition between services should be limited: "an NGO may only offer services and perform tasks that satisfy otherwise unmet real needs, or that complement or improve on inadequate resources or systems" (\#4.7.1). The

\footnotetext{
${ }^{43}$ Gibelman and Gelman (2004) have investigated the different types of wrongdoing by NGO managers worldwide, which include the cases mentioned here: creation of shadow companies, theft, resource mismanagement, support for activities and groups unrelated to the organization's interests, money laundering, misappropriation, embezzlement, forgery, unjustified pay awards, robbery, links with terrorism, disappearance of donations, misapplication of funds, etc.
} 
standard therefore excludes destructive competition and favors complementary action, though fair, direct competition is permissible when an NGO considers that it can perform a particular role better than another, or when the volume or variety of needs justifies the presence of several NGOs.

The standard considers competition with other NGOs (\#4.2.7.a) for funds or projects acceptable (though it does not say it is desirable). It encourages NGOs to create their own competitive advantages, but always acting fairly, relying on their own positive qualities and avoiding unjustified criticism and derogatory remarks about competitors; competition must be fair, based on truthful disclosure about the organization's scale, activities and representation.

The standard encourages NGOs to cooperate with other NGOs (\#4.7.2.b) through networking, ${ }^{44}$ exchange of knowledge and experience, respect and equality in mutual relations, and consensus in action. ${ }^{45}$ The standard does not give any specific recommendations for developing and maintaining alliances between organizations.

Competition/rivalry with the private and public sectors (the latter understood as a service provider competing with NGOs) is scarcely touched upon (\#4.7.3.a). Unfair competition is prohibited, but only in a very limited sense: "engaging in activities or providing services for profit, or contrary to the organization's mission and values" (\#4.7.3.a). In other words, the standard does not consider the case of NGOs competing with companies or other private institutions by, for example, selling products or services below cost, thanks to their donor financing. ${ }^{46}$ The standard accepts that criticism and public holding to account of the private sector are the natural domain of NGOs, but demands that criticism be exercised responsibly and that accusations be well founded.

Lastly, the standard encourages NGOs to work with companies and other institutions to "analyze problems, set goals and carry out projects, and also to obtain resources." It also recommends that they "develop models of cooperation and collaboration" (\#4.7.3.b). The treatment of relations between NGOs and companies is thus very unambitious. The possible forms of collaboration are omitted, with the result that there is no discussion of the associated ethical problems (Millar et al., 2004). ${ }^{47}$ The standard is silent about relations with unions. ${ }^{48}$

\section{Government}

The standard distinguishes three functions of government in relation to NGOs: as regulator (overseeing NGO operations, the social services they offer, international cooperation, etc.); as planner, coordinator and administrator of NGO resources and activities; and as financier of their activities or projects (which was dealt with earlier, in the section on relations with the contributors of funds) (\#4.8.1). It is worth noting that the standard does not appear to be

\footnotetext{
44 The networking recommendation appears in various places in the standard, probably to draw attention to the problem of the fragmentation of NGO activities. Goodin (2003, p. 23) also emphasizes the role of networking as the way the Third Sector operates, its way of forcing accountability on other actors, and a mechanism by which nonprofits are themselves held accountable.

${ }^{45}$ On the forms and problems of alliances between NGOs, see Ritchie (1995).

${ }^{46}$ This problem often arises, for example, in fair trade NGOs, which operate on the boundary between not-for-profit and for-profit enterprises (Lewis, 1998).

47 Goodin (2003) criticizes the recommendations for cooperation and competition of NGOs with governments and companies, arguing that the Third Sector is motivationally and organizationally different of the other two.

${ }^{48}$ On this subject, see Egels-Zandén and Hyllman (2006).
} 
written from an independent viewpoint, but rather seeks to protect NGOs against government interference and to actively support them by "bringing government opinion and action into line with the real needs" (\#4.8.3.e).

In their relations with regulatory bodies (\#4.8.2), NGOs are encouraged to show genuine cooperation and avoid taking unfair advantage of situations for their own benefit. The standard does not demand that NGOs obey the law, which is included in the principle of legality, but encourages them to voice their opinion and judgment on existing or proposed regulations, and to publicly denounce "any injustice they may detect, whether perpetrated by government or third parties" (\#4.8.2.b). It also mentions the duty to inform the regulator, as the monitoring body.

Relations between NGOs and government, as the coordinator of their activities, are to be based on independence "on the basis of non-subordination to government" (\#4.8.3.a), active commitment, resource optimization, participation in joint forums, support, and joint commitments. The standard also points out that NGOs "must promote and participate in raising government awareness of issues they know and have found to be important, bringing government opinion and action into line with the real needs" (\#4.8.3.e), as has already been said.

Society

Society is an important stakeholder of NGOs, which aim to solve large-scale problems that governments may not be able to tackle; which often present themselves to governments, companies and other stakeholders as representatives of society; and which must accept their social responsibility, just like other agents involved.

The standard (\#4.9) is fairly succinct in its treatment of relations between NGOs and society. It seems rather to lobby in NGOs' favor. It presents them "to society at large as a driving force for social change to build a better society" (\#4.9.a); and it calls on them to help "create an image of professionalism, responsibility and commitment in the NGO sector" (\#4.9.c) and to "make society aware of their real capacity to get things done" (\#4.9.d).

Specific duties of NGOs to society mentioned in the standard are: to promote citizen participation; "not to use the image of their target group [their clients] to put pressure on citizens or make them feel guilty" (\#4.9.e); to respect the individuality of the members of each group and avoid stereotypes; to be truthful in their advertising campaigns; to use these campaigns and their own image to support and defend their clients; and to avoid overly pessimistic, idealized, overgeneralized or discriminatory messages.

An important omission in this section is the duty of disclosure and accountability to society (the section on "communication - information" (\#4.3.5) refers only to donors). This omission does not agree with the public function of NGOs, their role as representatives of civil society, or the requirements established in codes and rules for companies. And it seems unlikely to help build trust in NGOs or strengthen their legitimacy (Lehr-Lehnardt 2005). 


\section{Conclusions: The Accountability of NGOs}

In the preceding pages, we have made abundant comments on the strengths and weaknesses of the standard. Here, we shall merely make some general observations with emphasis on the issues related to the accountability of NGOs.

1) The standard is based on a limited, very pragmatic concept of disclosure. Disclosure appears to be confined to donors, employees and volunteers (and even then, to a very limited extent); and also to the regulator. Duties of disclosure to important stakeholders, such as society and clients (the beneficiaries of NGOs' actions), are omitted.

2) A limited concept of disclosure entails also a limited concept of accountability (Lloyd, 2005) and, therefore, a possible "accountability gap" (Salamon et al., 2000). The standard does not devote sufficient attention to the principle that NGOs must render account of their activities to all their stakeholders. Rather, again taking a pragmatic approach, it seems to concentrate on donors and the authorities, besides members. It demonstrates excessive accountability "upwards" and too little accountability "downwards", which is NGOs' "Achilles heel" (Smillie, 1995). A broader concept of accountability would offer greater scope for reflection and selfcriticism, yet this does not appear to be the purpose of the standard, which, as we pointed out earlier, seems in some respects designed to bolster the power of the NGO sector, that is, the existing of large NGOs (which are the ones that were most directly involved in drafting the standard). This also suggests the need for further thought as well as theoretical and practical development of NGO accountability (Najam, 1996).

3) The standard leaves much to be desired in regard to dialogue between stakeholder and client, participation and involvement in planning NGO projects, and at the different stages of implementation, monitoring and reporting. ${ }^{49}$ The demands commonly placed on companies in writings on social responsibility should be all applicable to not-for-profit social institutions, where some of the usual objections to stakeholder participation are less convincing.

4) In the stakeholder approach, an NGO must be accountable to a wide range of stakeholders; but this is not easy, since NGO's responsibilities are naturally varied, complex and diffuse (McDonald 1999), and also because the means of enforcing the standard are very weak. In any case, the standard pays no attention to the need to balance the demands of all these stakeholders against each other; nor does it suggest how this might be done. ${ }^{50}$

5) The most important stakeholders for NGO accountability must be the clients themselves. Therefore, an NGO must "have some level of formal or semi-formal accountability to those it wishes to see empowered - its constituents" (Kilby, 2006; cf. Smith-Sreen, 1995). In any case, this accountability to clients is ethical and social; therefore, it falls within the scope of social responsibility (Argandoña, 2006) and so must be the result of an internal attitude and, where appropriate, a commitment to an industry code or standard such as the one we are considering

\footnotetext{
49 Ebrahim (2003) distinguishes between four levels of participation by societies and communities in the NGOs' projects: information and consultation about projects, public involvement in project-related activities, negotiation, bargaining and even, veto power on decisions, and people's own initiatives.

${ }^{50}$ Accountability means that the organization must, first, identify its stakeholders and stakeholder groups, second, to prioritize the stakeholders and to be explicit about that prioritization, and third, define the relationships between the organization and each stakeholder group, as expressed through the intentions and views of the organization, the current laws, rules and quasi-legal regulations, and the views of the stakeholders themselves (Gray et al., 2006).
} 
here. Furthermore, accountability to clients is not independent of accountability to other stakeholders, ${ }^{51}$ as the two may conflict.

6) The broad meaning of accountability that we propose asks for the involvement of NGOs' leaders with accountability policy and practices, integrating accountability into strategic planning, employing internally driven forms of self-regulation and integrating learning from accountability evaluations into organizational practices (Bies, 2001). And the voluntary aspect of the standard is compatible with this point of view, although it is not promoted or encouraged by it.

7) The standard takes sides with NGOs, in that it avoids the necessity of opening a general dialogue among NGOs and other stakeholders. The organizations are responsible for engaging in an honest and open democratic debate regarding their policies and actions, and this implies that the organization must provide an honest and open account of their actions to their stakeholders (Unerman and Bennett, 2004).

8) The standard envisages instruments (codes, reports, audits, etc.) and processes for accountability (evaluations, consultations, complaint mechanisms, etc.) (Ebrahim, 2003). But, as Mulgan points out (2003), the crucial thing is, to what extent these instruments and processes lead to a change of behavior.

9) In the standard, accountability is understood as a disciplinary mechanism, not as a driver for change (Young, 2000), ensuring continuous improvement of processes and decisions; as rulebound responses of organizations that become important when things go wrong, more than a process that is understood as part of the daily organizations life of the NGO (Fry, 1995). Although continuous improvement is emphasized, it is limited to traditional mechanisms, in which stakeholder dialogue (above all with external stakeholders, especially clients and society) plays only a minor role.

10) The standard is very focused on the environment of Spanish NGOs and pays no attention to the problems resulting from their activities in developing countries.

11) The standard seems to be particularly focused on the development of ethical management systems in NGOs, perhaps assuming that this will be sufficient to foster fully ethical behavior in organizations and satisfy the demands for compliance disclosure. While it cannot be expected to set forth the requirements of an ethical management system in detail, not doing so may limit the scope of the ethical management system to mere compliance with a set of administrative requirements.

12) The standard's authors have apparently tried to broaden its content, making it more of a general-purpose code. This is a valid option, and a very appropriate one, because NGOs should be organized and managed according to their particular view of the common good, as they have a right to address human needs in whatever way they see fit. They must explain their visions, missions and policies, and be accountable for them. What NGOs need is not regulation, but oversight, insofar as no real harm is done.

\footnotetext{
${ }^{51}$ Tandon (1995) identifies other accountabilities of NGOs: to their mission and values, to their mission fulfillment, and to civil society, in which they are actors.
} 


\section{References}

Abramson, D.M. (1999), "A critical look at NGOs and civil society as means to an end in Uzbekistan," Human Organization, 58 (3), pp. 240-250.

Aenor (A sociación Española de Normalización y Certificación) (2004), “Ética. Sistema de gestión de las ONG," UNE 165011 EX. Madrid: A enor.

Argandoña, A. (2004), "On ethical, social and environmental management systems," J ournal of Business Ethics, 51 (1), pp. 41-52.

Argandoña, A. (2006), "From ethical responsibility to corporate social responsibility," presented at the 6th International Symposium on Catholic Social Thought and Management Education "The Good Company. Catholic Social Thought and Corporate Social Responsibility in Dialogue", Rome, October 5-7.

Bies, A.L. (2001), "Accountability, organizational capacity, and continuous improvement: Findings from Minnesota's nonprofit sector," New Directions for Philanthropic Fundraising, 31, pp. 51-80.

Brown, L.D. and A. Kalegaonkar (2002), "Support organizations and the evolution of the NGO sector," Nonprofit and Voluntary Sector Quarterly, 31 (2), pp. 231-258.

Coordinadora de ONG para el desarrollo - Congde (1998), "Código de conducta de las ONG de desarrollo de la Congde" (www.congde.org).

Cornwall, A., H. Lucas, and K. Pasteur (2000), "Introduction: accountability through participation: developing workable partnership models in the health sector," IDS Bulletin, 31 (1), pp. 1-13.

Ebrahim, A. (2003), "Accountability in practice: mechanisms for NGOs," World Development, $31(5)$, pp. 813-829.

Edwards, M. (2000), "NGO Rights and Responsibilities: A New Deal for Global Governance," London: The Foreign Policy Centre/NCVO.

Edwards, M. and D. Hulme (1996), "Too close for comfort? The impact of official aid on nongovernmental organizations," World Development, 24 (6), pp. 961-973.

Egels-Zandén, N. and P. Hyllman (2006), " Exploring the effects of union-NGO relationships on corporate responsibility: the case of the Swedish Clean Clothes Campaign," Journal of Business Ethics, 64 (3), pp. 303-316.

Eisenberg, P. (2000), "The nonprofit sector in a changing world," Nonprofit and Voluntary Sector Quarterly, 29 (2), pp. 325-330.

Fisher, W.F. (1997), "Doing good? The politics and antipolitics of NGO practices," Annual Review of Anthropology, 26, pp. 439-464.

Foote, D. (2001), "The question of ethical hypocrisy in human resource management in the UK and Irish charity sectors," J ournal of Business Ethics, 34, pp. 25-38. 
Fowler, A. (1997), "Striking a Balance. A Guide to Enhancing the Effectiveness of Nongovernmental Organizations in International Development," London, Earthscan Publications.

Fry, R. (1995), "Accountability in organizational life: problem or opportunity for nonprofits?," Nonprofit Management and Leadership, 6 (2), pp. 181 - 196.

Gibelman, M. and S.R. Gelman (2001), "Very public scandals: nongovernmental organizations in trouble," Voluntas: International Journal of Voluntary and Nonprofit Organizations, 12 (1), pp. 49-66.

Gibelman, M. and S.R. Gelman (2004), "A loss of credibility: patterns of wrongdoing among nongovernmental organizations," Voluntas: International Journal of Voluntary and Nonprofit Organizations, 15 (4), pp. 355-381.

Glaeser, E.L. (2002), "The governance of not-for-profit firms," Harvard Institute of Economic Research," Harvard University.

Goodin, R.E. (2003), "Democratic accountability: the Third Sector and all," The Hauser Center for Nonprofit Organizations, The J ohn F. Kennedy School of Government, Working Paper No. 19.

Gray, R., J. Bebbington, and D. Collison (2006), "NGOs, civil society and accountability: making the people accountable to capital," Accounting, Auditing and Accountability Journal, 19 (3), pp. 319-348.

Independent Sector (2004), "Statement of Values and Code of Ethics for Nonprofit and Philanthropic Organizations," Washington, D.C., The Independent Sector.

InterAction (2006), "InterAction PVO Standards" (www.interaction.org).

Kilby, P. (2006), "Accountability for empowerment: dilemmas facing non-governmental organizations," World Development, 34 (6), pp. 951-963.

Leader, N. (1999), "Codes of conduct: who needs them?," Relief and Rehabilitation Network Newsletter, March (www.odihpn.org).

Lehr-Lehnardt, R. (2005), "NGO legitimacy: Reassessing democracy, accountability and transparency," Cornell Law School Paper Series.

Lewis, D. (1998), "Nongovernmental organizations, business, and the management of ambiguity," Nonprofit M anagement and Leadership, 9 (2), pp. 135-152.

Light, P.C. (2000), "M aking Nonprofits Work," Washington, D.C., Brookings Institution.

Lloyd, R. (2005), "The role of NGO self-regulation in increasing stakeholder accountability," London, One World Trust.

MacDonald, C., M. McDonald, and W. Norman (2002), "Charitable conflicts of interest," J ournal of Business Ethics, 39, pp. 67-74.

McDonald, C. (1999), "Internal control and accountability in non-profit human service organizations," A ustralian J ournal of Public Administration, 58 (1), pp. 11-22. 
Martens, K. (2002), "Mission impossible? Defining non-governmental organizations," Voluntas: International J ournal of Voluntary and Nonprofit Organizations, 13 (3), pp. 271-285.

Millar, C.J .C.M., C.J . Choi, and S. Chen (2004), "Global strategic partnerships between the MNEs and NGOs: drivers of change and ethical issues," Business and Society Review, 109 (4), pp. 395-414.

Mulgan, R. (2003), "Holding Power to Account: Accountability in Modern Democracies," New York, NY, Palgrave MacMillan.

Naidoo, K. (2004), "The end of blind faith? Civil society and the challenge of accountability, legitimacy and transparency," A ccountA bility Forum, 2, pp. 14-23.

Najam, A. (1996), "NGO accountability: a conceptual framework," Development Policy Review, 14 (4), pp. 339-353.

Nalinakumari, B. and R. MacLean (2005), "NGOs: A primer on the evolution of the organizations that are setting the next generation of 'regulations'," Environmental Quality Management, 14 (4), pp. 1-21.

Ritchie, C. (1995), "Coordinate? Cooperate? Harmonize? NGO policy and operational conditions," Third World Quarterly, 16 (3), pp. 513-524.

Ruiz, J.I. (2000), “El sector no lucrativo en España," Madrid: Fundación BBV.

Salamon, L.M., L.C. Hems, and K. Chinnock (2000), "The non-profit sector: for what and for whom?," The J ohns Hopkins Center for Civil Society Studies, Working Paper No. 37.

Shea, C. (2004), "NGO accreditation and certification: the way forward? An evaluation of the development community experience," presented at the International Council on Human Rights Policy International Meeting on Global Trends in Human Rights - Before and After September 11.

Sidel, M. (2003), "Trends in nonprofit self-regulation in the Asia Pacific Region: initial data on initiatives, experiments and models in seventeen countries," (www.asianphilanthropy.org).

Smillie, I. (1995), "The Alms Bazaar: Altruism under Fire - Non-profit Organizations and International Development," London, Intermediate Technology.

Smith-Sreen, P. (1995), "Accountability in Development Organizations: Experiences of Women's Organizations in India," New Delhi, Sage.

Tandon, R. (1995), "Board games: governance and accountability," in M. Edwards and D. Julme (Eds.), "NGO Performance and Accountability," London: Earthscan Publications.

The Economist (2000), "NGOs: Sins of the secular missionaries," J anuary 29.

Unerman, J. and M. Bennett (2004), "Increased stakeholder dialogue and the internet: towards greater corporate accountability or reinforcing capitalist hegemony?," Accounting, Organizations and Society, 29 (7), pp. 658-707.

Unerman, J. and B. O'Dwyer (2006), "Theorising accountability for NGO advocacy," Accounting, Auditing and Accountability J ournal, 19 (3), pp. 349-376.

USAID (1995), "New partnership initiative: NGO Empowerment" (www.usaid.gov). 
Vakil, A.C. (1997), "Confronting the classification problem: toward a taxonomy of NGOs," World Development, 25 (12), pp. 2057-2070.

Vernis, A., M. Iglesias, B. Sanz, and A. Saz (2004), "Los retos en la gestión de las organizaciones no lucrativas," Barcelona, Granica.

Wango (World Association of Non-Governmental Organizations) (2004), "Code of Ethics and Conduct for NGOs" (www.wango.org).

Wells, C. (2006), "Holding charities accountable; some thoughts from an ex-regulator," Boston College Law School Faculty Papers, No. 184.

Young, I.M. (2000), "Inclusion and Democracy," Oxford, Oxford University Press.

Zaidi, S. (1999), "NGO failure and the need to bring back the State," Journal of International Development, 11 (2), pp. 259-271. 